NOTE

\title{
Antiserum to the gp116 glycoprotein of yellow head virus neutralizes infectivity in primary lymphoid organ cells of Penaeus monodon
}

\author{
Wanchai Assavalapsakul, Witoon Tirasophon*, Sakol Panyim
}

Institute of Molecular Biology and Genetics, Mahidol University, Salaya Campus, 25/25 Phuttamonthol 4 Rd., Salaya, Phuttamonthol, Nakorn Pathom 73170, Thailand

\begin{abstract}
Yellow head virus (YHV) is an invertebrate nidovirus that has caused mass mortality of cultured Penaeus monodon in Asia. In this study, we investigated whether mouse polyclonal antiserum raised against the YHV gp116 or gp64 structural glycoproteins could neutralize YHV infectivity as determined using an in vitro quantal assay in primary cultures of lymphoid organ cells. Antigp116 antiserum showed virus-neutralizing activity whereas anti-gp64 antiserum failed to inhibit infection. The results suggest that gp116 antiserum blocks binding of virions to cellular receptors to facilitate YHV entry into lymphoid organ cells.
\end{abstract}

KEY WORDS: Yellow head virus · Primary cell culture $\cdot$ Lymphoid organ $\cdot$ Penaeus monodon $\cdot$ gp116 gp64 $\cdot$ Neutralization

Resale or republication not permitted without written consent of the publisher

\section{INTRODUCTION}

Yellow head virus (YHV) has caused mass mortalities in Penaeus monodon cultured in Asia and is an enveloped virus with a positive-sense, single-stranded RNA genome (Wongteerasupaya et al. 1995, Tang \& Lightner 1999). Sequence analysis of the genomes of YHV and the closely related gill-associated virus (GAV) from Australia has identified a long open reading frame (ORF) that contains motifs with distinct homologies to function domains present in nidovirus ORF1b coding sequences (Cowley et al. 1999, 2000, Sittidilokratna et al. 2002). Also, as in all nidoviruses, YHV and GAV possess a pseudoknot element in the genome region in which ORF1a overlaps ORF1b, thus facilitating translation of an ORF1a-1b polyprotein (pp1ab) by a -1 ribosomal frameshift mechanism (Cowley et al. 2000, Sittidilokratna et al. 2002). Based on their genome organisation and on the transcription of 3 '-coterminal subgenomic RNAs in GAV (Cowley et al. 2000), YHV and GAV have recently been classified in new taxa within the Nidovirales, family Roniviridae, genus Okavirus (Cowley et al. 2000, Cowley \& Walker 2002, Mayo 2002, Sittidilokratna et al. 2002).

Coronavirus particles contain 3 or 4 prominent structural proteins: an RNA-associated nucleocapsid (N) protein, an integral membrane $(\mathrm{M})$ protein, a spike (S) glycoprotein and some viruses also possess a surfaceexposed, hemagglutinin-esterase (HE) protein (Spaan et al. 1988). As its name implies, the $\sim 180 \mathrm{kDa} S$ glycoprotein constitutes the spikes projecting from the virion envelope and possesses important biological activities associated with cell receptor binding and membrane fusion to allow cell entry (Holmes et al. 1981, Williams et al. 1991, Spaan et al. 1988, Klasse \& Sattertau 2002). Monoclonal or polyclonal antibodies to spike proteins of coronaviruses of mice (Luytjes et al. 1989), birds (Mockett et al. 1984), pigs (Jimenez et al. 1986), cats (Corapi et al. 1992) and cattle (Deregt \& Babiuk 1987) have been shown to neutralize virus infectivity.

YHV particles are morphologically distinct from coronaviruses in that they are rod-shaped with diffuse 
surface projections (Wongteerasupaya et al. 1995). YHV virions contain 3 major structural proteins with estimated molecular masses of $116 \mathrm{kDa}$ (gp116), $64 \mathrm{kDa}$ (gp64) and $20 \mathrm{kDa}$ (p20) (Nadala et al. 1997, Wang \& Chang 2000, Jitrapakdee et al. 2003). The glycoproteins gp116 and gp64 are proteolytic products of the polyprotein encoded by the ORF3 gene. The ORF3 polyprotein contains 6 highly hydrophobic, predicted transmembrane domains and proteolytic cleavage occurs at the C-terminal positions of transmembrane domains 2 and 5 (Jitrapakdee et al. 2003). Cleavage generates a $\sim 28 \mathrm{kDa} N$-terminal ORF3 fragment comprising a putative triple-membrane spanning protein of unknown function in addition to the membraneanchored gp116 and gp64 glycoproteins that are incorporated into virions. According to the predicted topology of the ORF3 polyprotein, gp116 is a type III transmembrane glycoprotein anchored in the envelope at 2 positions in its $\mathrm{C}$-terminus with both $\mathrm{N}$ - and $\mathrm{C}$ termini exposed and gp64 is a type I glycoprotein anchored at its C-terminal transmembrane domain. The amino acid sequences of gp116 and gp64 contain no heptad-repeat patterns indicative of the coiled-coil structures found in the structural glycoproteins of coronaviruses and toroviruses (de Groot et al. 1987), which likely accounts for the absence of rigid stemcontaining surface peplomers on the YHV particle. The distinct virion structure of YHV thus raises several interesting questions concerning the mechanism of infection and which structural glycoprotein facilitates cell attachment and/or entry. In this study we have obtained evidence that gp116 but not gp64 contains virus-neutralizing epitopes and thus has an essential role in infecting susceptible cells.

\section{MATERIALS AND METHODS}

Virus purification. A Thai YHV isolate (kindly provided by Dr. Boonsirm Withyachumnarnkul) was used to infect 200 juvenile Penaeus monodon shrimp (average weight $20 \mathrm{~g}$ ) by intramuscular injection as previously described (Wongterrasupaya et al. 1995). At 48 to $72 \mathrm{~h}$ post injection, hemolymph was collected and pooled and YHV was purified using Urograffin (Schering) gradient centrifugation (Wongteerasupaya et al. 1995). Purified YHV was aliquoted and stored frozen at $-80^{\circ} \mathrm{C}$.

Primary lymphoid (Oka) cell cultures. Primary cell cultures were prepared from the lymphoid (Oka) organ of Penaeus monodon as previously described (Assavalapsakul et al. 2003). Briefly, Oka organs were collected from approximately 100 juvenile P. monodon (average weight $20 \mathrm{~g}$ ), washed 6 times with sterile $2 \times$ Leibovitz's L-15 (GIBCO, BRL) containing 15\% fetal bovine serum, $5 \%$ lactabumin, 100 units $\mathrm{ml}^{-1}$ penicillin and $100 \mu \mathrm{g} \mathrm{ml} \mathrm{m}^{-1}$ streptomycin and then minced into small pieces in the same medium. The minced tissue was seeded onto a 96-well tissue culture plate in the same medium supplemented with $15 \%$ shrimp meat extract. The cells were grown to monolayer at $28^{\circ} \mathrm{C}$.

Anti-gp116 and anti-gp64 polyclonal antisera production. Gel slices containing gp116 or gp64 of YHV were excised from a Coomassie Brilliant Blue-stained $10 \%$ SDS-polyacrylamide gel. Each gel slice was dried under vacuum using a speedvac centrifuge and then ground in liquid nitrogen into a fine powder. The powdered acrylamide containing gp116 or gp64 was emulsified in complete Freund's adjuvant (Sigma Chemical) and injected peritoneally into female BALB/c mice as described by Harlow \& Lane (1988). The mice were subsequently injected 3 times at 2 wk intervals with the same antigen emulsified with incomplete Freund's adjuvant (Sigma Chemical). Antiserum was collected $1 \mathrm{wk}$ after the third injection.

Immunoblot analysis. YHV proteins (500 ng) were resolved in a $10 \%$ SDS-polyacrylamide gel and transferred onto nitrocellulose membranes using a SemiDry transblot apparatus (BioRad). The membranes were incubated with either anti-gp116 or anti-gp64 antiserum diluted 1:2000 in 5\% skim milk in phosphatebuffered saline containing $0.2 \%$ Tween-20 (PBST) for $1 \mathrm{~h}$ at room temperature $\left(25^{\circ} \mathrm{C}\right)$. Excess antiserum was removed by successive washes in PBST, and the membrane was then probed with horseradish peroxidaseconjugated goat anti-mouse secondary antibody (Sigma Chemical) diluted 1:4000 in 5\% skim milk in PBST. Antigen-antibody complexes were visualized using the ECL Plus Western Blotting Detection Reagent (Amersham Pharmacia Biotech).

YHV inhibition tests in primary cell cultures. Serial 10 -fold dilutions of purified YHV were prepared in the same culture medium as described above for cell cultivation and were then preincubated with anti-gp116, anti-gp64 or irrelevant antiserum to human growth hormone at a dilution of 1:500 for $90 \mathrm{~min}$ at room temperature. Aliquots $(50 \mu \mathrm{l})$ of each antiserum-YHV mixture were inoculated into 4 wells and incubated for $90 \mathrm{~min}$ at room temperature. After incubation, $150 \mu \mathrm{l}$ of medium was added and the cells were maintained at $28^{\circ} \mathrm{C}$ for $7 \mathrm{~d}$. Viral infectivity was determined by crystal violet staining to distinguish between viable and non-viable cells and $\mathrm{TCID}_{50}$ end points were determined as described by Reed \& Muench (1938).

\section{RESULTS AND DISCUSSION}

The specificity of polyclonal antisera against gp116 and gp64 was demonstrated by their binding only to proteins with molecular mass of $128 \mathrm{kDa}$ (Fig. 1B) or 
$71 \mathrm{kDa}$ (Fig. 1C) derived from purified YHV. The sizes of the immuno-reactive proteins corresponded to the 2 major structural proteins from purified YHV (Fig. 1A), although their estimated masses were apparently different from those previously reported (Jitrapakdee et

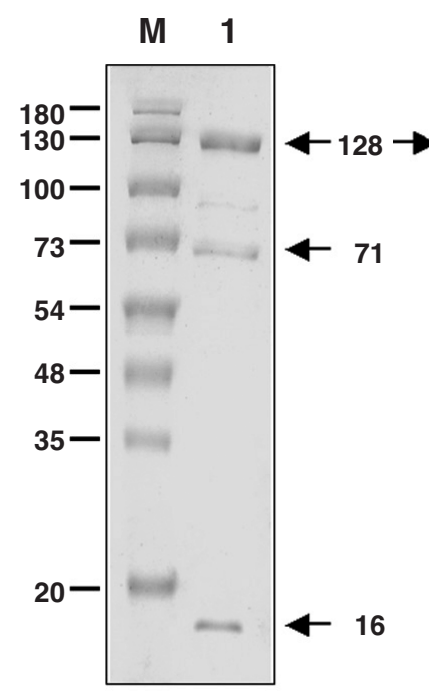

(A)
1

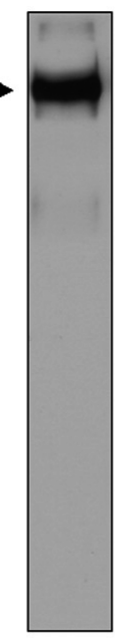

(B)

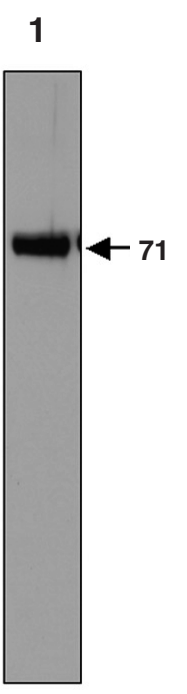

(C)
Fig. 1. SDS-PAGE and western blot analysis of proteins of purified yellow head virus (YHV). (A) Coomassie blue-stained SDS-polyacrylamide gel of purified YHV. M: protein marker standards (Fermentas) Numbers on the left represent molecular mass of standard proteins in $\mathrm{kDa}$. Lane 1: protein from purified YHV. Identical gels were transferred to a nylon membrane and probed with (B) anti-gp116 and (C) anti-gp64 antisera

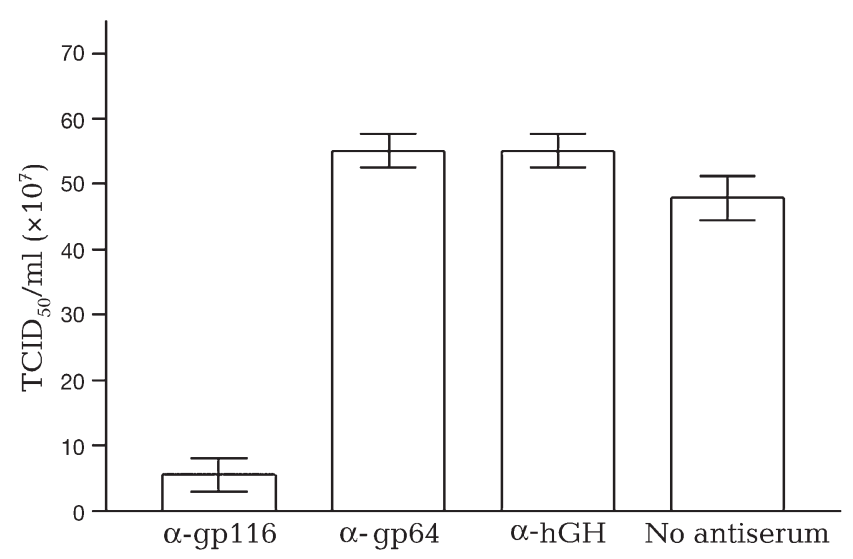

Fig. 2. Inhibition of yellow head virus (YHV) infectivity in primary lymphoid organ cell cultures by antisera to YHV gp116 and gp64 glycoproteins. Serial 10-fold dilutions of YHV were pre-incubated with anti-gp116 ( $\alpha$-gp116), anti-gp64 ( $\alpha$-gp64), or anti-human growth hormone $(\alpha-h \mathrm{GH})$ and then used to challenge confluent monolayers of Oka organ cells in a 96-well plate. Standard deviation bars of the $\mathrm{TCID}_{50} \mathrm{ml}^{-1}$ value were obtained from 3 independent experiments al. 2003). Even so, it is most likely that the respective 128 and $71 \mathrm{kDa}$ protein bands recognized by our antisera corresponded to the gp116 and gp64 proteins previously reported. The apparent differences in molecular mass prediction may be due to differences in gel electrophoresis conditions or to the standard markers used. The apparent titer of the 2 antibodies was comparable as determined by dot blots in which both antisera could readily detect the corresponding proteins at the level of $5 \mathrm{ng}$ (data not shown).

Incubation of anti-gp116, anti-gp64 and irrelevant polyclonal antisera with YHV prior to challenge of Oka organ cell monolayers resulted in neutralization of YHV infectivity only with anti-gp116 (Fig. 2). In 3 separate experiments, there was an approximate 1-log reduction in $\mathrm{TCID}_{50} \mathrm{ml}^{-1}$ compared to that from controls without antiserum treatment. The reduction was antiserum specific since YHV preincubation with anti-human growth hormone antiserum did not affect viral titer. Interestingly, YHV preincubation with anti-gp64 did not inhibit YHV infectivity and similar results were observed for 3 independent experiments. This suggests that the gp116 surface glycoprotein of YHV contains virus neutralizing antigenic epitopes and that it may be involved in cell attachment and entry. Thus, it may be a good target for development of antibody-based, antiviral protectants or therapies. Although our anti-gp64 antiserum showed no inhibition to YHV infectivity, involvement of gp64 in YHV infectivity cannot be excluded. The fact that both anti-gp116 and anti-gp64 antiserum were produced against denatured proteins means that they would recognize mainly linear epitopes of the corresponding antigens. Thus, if neutralizing epitopes of gp64 were conformationally specific, it is possible that antiserum to linear epitopes would fail to neutralize its activity. Recently, an oral treatment strategy using bacterially expressed structural protein VP28 of white spot syndrome virus (WSSV) has been reported to lower the mortality rate of Penaeus monodon challenged with WSSV (Witteveldt et al. 2004). Our results suggest that similar experiments may be worthwhile using bacterially expressed gp116 to feed shrimp prior to challenge with YHV.

Acknowledgements. We thank K. Pootanakit for his comments on this manuscript. This work was supported by the Thailand Research Fund to S.P. W.A. is a recipient of a Thailand Research Fund Royal Golden Jubilee Scholarship.

\section{LITERATURE CITED}

Assavalapsakul W, Smith DR, Panyim S (2003) Propagation of infectious yellow head virus particles prior to cytopathic effect in primary lymphoid cell cultures of Penaeus monodon. Dis Aquat Org 55:253-258 
Corapi WV, Olsen CW, Scott FW (1992) Monoclonal antibody analysis of neutralization and antibody-dependent enhancement of feline infectious peritonitis virus. J Virol 66: 6695-6705

Cowley JA, Walker PJ (2002) The complete genome sequence of gill-associated virus of Penaeus monodon prawns indicates a gene organisation unique among nidoviruses. Arch Virol 147:1977-1987

Cowley JA, Dimmock CM, Wongteerasupaya C, Boonsaeng V, Panyim S, Walker PJ (1999) Yellow head virus from Thailand and gill-associated virus from Australia are closely related but distinct prawn viruses. Dis Aquat Org 36:153-157

Cowley JA, Dimmock CM, Spann KM, Walker PJ (2000) Gillassociated virus of Penaeus monodon prawns: an invertebrate virus with ORF1a and ORF1b genes related to arteriand coronaviruses. J Gen Virol 81:1473-1484

de Groot RJ, Luytjes W, Horznek MC, Van der Zeijst BAM, Spaan WJM, Lenstra JA (1987) Evidence for a coiled-coil structure in the spike proteins of coronaviruese. J Mol Biol 196:963-966

Deregt D, Babiuk LA (1987) Monoclonal antibodies to bovine coronavirus: characteristics and topographical mapping of neutralizing epitopes on the E2 and E3 glycoproteins. Virology 68:410-420

Harlow E, Lane D (1988) Antibodies: a laboratory manual. Cold Spring Harbor Press, Cold Spring Harbor, NY

Holmes KV, Doller EW, Behnke JN (1981) Analysis of the functions of coronavirus glycoproteins by differential inhibition of synthesis with tunicamycin. Adv Exp Med Biol 142:133-142

Jimenez G, Correa I, Melgosa MP, Bullido MJ, Enjuanes L (1986) Critical epitopes in transmissible gastroenteritis virus neutralization. J Virol 60:131-139

Jitrapakdee S, Unajak S, Sittidilokratna N, Hodgson RAJ, Cowley JA, Walker PJ, Panyim S, Boonsaeng V (2003) Identification and analysis of gp116 and gp64 structural glycoproteins of yellow head nidovirus of Penaeus monodon shrimp. J Gen Virol 84:863-873

Editorial responsibility: Timothy Flegel, Bangkok, Thailand
Klasse PJ, Sattentau QJ (2002) Occupancy and mechanism in antibody-mediated neutralization of animal viruses. J Gen Virol 83:2091-2108

Luytjes W, Geerts D, Posthumus W, Meloen R, Spaan W (1989) Amino acid sequence of a conserved neutralizing epitope of murine coronaviruses. J Virol 63:1408-1412

Mayo MA (2002) A summary of taxonomic changes recently approved by ICTV. Arch Virol 147:1655-1656

Mockett APA, Cavanagh D, Brown TDK (1984) Monoclonal antibodies to the $\mathrm{S} 1$ spike and membrane proteins of avian infectious bronchitis coronavirus strain Massachusetts M41. J Gen Virol 65:2281-2286

Nadala ECB, Tappy LM, Loh PC (1997) Yellow-head virus: a rhabdovirus like pathogen of penaeid shrimp. Dis Aquat Org 31:141-146

Reed LJ, Muench H (1938) A simple method of estimating fifty percent end points. Am J Hyg 27:493-497

Sittidilokratna N, Hodgson RAJ, Cowley JA, Jitrapakdee S, Boonsaeng V, Panyim S, Walker PJ (2002) Complete ORF1b-gene sequence indicates yellow head virus is an invertebrate nidovirus. Dis Aquat Org 50:87-93

Spaan W, Cavanagh D, Horzinek MC (1988) Coronavirus: structure and genome expression. J Gen Virol 69:2939-2952

Tang KFJ, Lightner DV (1999) A yellow head virus gene probe: nucleotide sequence and application for in situ hybridization. Dis Aquat Org 35:165-173

Wang YC, Chang PS (2000) Yellow head virus infection in the giant tiger prawn Penaeus monodon cultured in Taiwan. Fish Pathol 35:1-10

Williams RK, Jiang GS, Holmes KV (1991) Receptor for mouse hepatitis virus is a member of the carcinoembryonic antigen family of glycoproteins. Proc Natl Acad Sci USA 88: 5533-5536

Witteveldt J, Cifuentes CC, Vlak JM, Van Hulten CW (2004) Protection of Penaeus monodon against white spot syndrome virus by oral vaccination. J Virol 78:2057-2061

Wongteerasupaya C, Sriurairatana S, Vickers JE, Akrajamorn A and 5 others (1995) Yellow-head virus of Penaeus monodon is an RNA virus. Dis Aquat Org 22:45-50

Submitted: December 17, 2003; Accepted: July 26, 2004

Proofs received from author(s): January 12, 2005 